\title{
PENGUATAN PENDIDIKAN MELALUI LINGKUNGAN PEMBELAJARAN DALAM MENINGKATKAN KUALITAS BELAJAR SISWA DI MADRASAH
}

\author{
Machfudz \\ Fakultas Tarbiyah dan Ilmu Keguruan (FTIK) IAIN Jember \\ Email: machfudzkemenag@gmail.com
}

\begin{abstract}
In the world of education, the environment is one of the elements of education. Because if it is lacking or missing one of them, then it can not be said as education, closely related to education. The learning environment is an important element that affects students' learning, resulting in a variety of interactions in student outcomes and quality of learning. The role of the learning environment in improving academic quality is the presence of supportive, good classroom management, quality learning resources, and good classroom management. Can affect how students learn patterns so that the quality of their assessment is good, and proven by the presence of quality output. Because in the world of education, in addition to assessment skills are considered necessary, as a benchmark of students' ability in their learning outcomes. The role of the learning environment in improving the quality of non-academic is through extracurricular, ethical and moral. As a teacher and educator the teacher can measure the students' non-academic skills, as well as see the progress of their students' behavior.
\end{abstract}

Keywords: Education, Learning Environment, Learning quality

\begin{abstract}
Abstrak
Dalam dunia pendidikan, lingkungan merupakan salah satu hal dari unsur pendidikan. Karena jika kurang ataupun hilang salah satunya, maka tidak bisa dikatakan sebagai pendidikan, Erat kaitannya dengan pendidikan. Lingkungan pembelajaran termasuk unsur penting yang berpengaruh pada belajar siswa sehingga menimbulkan berbagai interaksi pada hasil dan kualitas belajar siswa. Peran lingkungan pembelajaran dalam meningkatkan kualitas akademik adalah dengan adanya sarpras yang mendukung, menejemen kelas yang baik, sumber belajar yang berkualitas, serta pengelolaan kelas yang baik. Dapat mempengaruhi bagaimana pola belajar siswa sehingga kualitas penilaian mereka pun baik, dan di buktikan dengan adanya output yang berkualitas pula. Karena dalam dunia pendidikan, selain skill penilaian pun dianggap perlu, sebagai tolak ukur kemampuan siswa dalam hasil belajarnya. Peran lingkungan pembelajaran dalam meningkatkan kualitas non akademik adalah melalui ekstakulikuler, etika dan akhlak. Sebagai seorang pengajar dan pendidik guru dapat mengukur kemampuan skill non akademik siswa, serta melihat perkembangan tingkah laku siswanya.
\end{abstract}

Kata Kunci: Pendidikan, Lingkungan Belajar, kualitas Pembelajaran

\section{PENHADULUAN}

Pendidikan merupakan usaha meningkatkan dan mengembangkan potensi diri dalam segala aspeknya melalui proses pembelajaran. Hal ini sesuai dengan pengertian Undang-undang Sistem Pendidikan Nasional No.20 tahun 2003 pasal 1 ayat 1 yang menyebutkan :"Pendidikan adalah 


\section{Machfudz}

usaha sadar dan terencana untuk mewujudkan suasana belajar dan proses pembelajaran agar peserta didik (siswa) secara aktif mengembangkan potensi dirinya untuk memiliki kekuatan spiritual keagamaan, pengendalian diri, kepribadian, kecerdasan, akhlak mulia serta ketrampilan yang diperlukan dirinya, masyarakat, bangsa dan Negara."

Dalam Kamus Besar Bahasa Indonesia mendefinisikan kata "Pembelajaran" berasal dari kata "ajar" yang berarti petunjuk yang diberikan kepada orang supaya di ketahui atau diturut, sehingga dari kata "Pembelajaran" tersebut dapat diartikan sebagai proses, cara, perbuatan menjadikan orang atau makhluk hidup belajar, mengetahui dan memahami melalui apa yang di ajarkan. $^{2}$

Dalam Al-Qur'an pun jelas di sebutkan mengenai pentingnya pendidikan dan juga lingkungan pendidikan yang berpengaruh di dalamya. Firman Allah dalam Al-Qur'an surat AlBaqoroh ayat 31

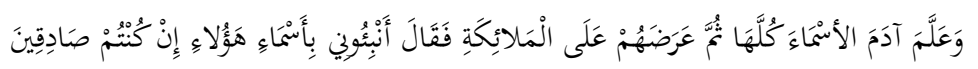

Artinya : "Dan Dia ajarkan kepadanya (Adam) nama-nama (Benda) semuanya, kemudian dia perlihatkan kepadanya para malaikat seraya berfirman, "sebutkakan Kepada - Ku nama semua (benda) ini, jika kamu yang benar". (Al-Baqoroh : $31)^{3}$

Firman Allah dalam Al-Qur'an surat At-Tahrim ayat 6.

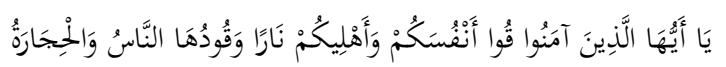

Artinya : "Wahai orang - orang yang beriman jagalah dirimu dan keluargamu dari api neraka. Yang bahannya dari manusia dan batu." (Q.s Al-Tahrim : 6) ${ }^{4}$

Dalam suatu pembelajaran, proses belajar mengajar merupakan salah satu aspek dari lingkungan yang diorganisir. Lingkungan ini di atur serta di awasi agar kegiatan belajar mengajar terarah sesuai dengan tujuan pendidikan. Lingkungan belajar yang baik adalah lingkungan yang menantang dan merangsang para siswa untuk belajar lebih aktif, memberikan rasa aman dan kepuasan serta mencapai tujuan yang diharapkan. Adapun lingkungan secara umum diartikan sebagai kesatuan ruang dengan segala benda, daya, keadaan dan makhluk hidup. Termasuk manusia dan perilakunya yang mempengaruhi kelangsungan kehidupan dan kesejahteraan.

\footnotetext{
${ }^{1}$ Undang-undang Sistem Pendidikan Nasional No. 20 tahun 2003, (Bandung: Citra Umbara, 2006), 72.

${ }^{2}$ Departemen Pendidikan Nasional, Kamus Besar Bahasa Indonesia,( Jakarta: Balai Pustaka, 2007)

${ }^{3}$ Al-Qur'an, 1:31

${ }^{4}$ Al-Qur'an, 66:6
} 
Lingkungan dalam lingkup pendidikan, yaitu segala sesuatu yang berada di luar diri anak, dalam alam semesta ini. Antara manusia dan lingkungan memiliki hubungan timbal balik, lingkungan mempengaruhi manusia dan manusia juga mempengaruhi lingkungan sekitarnya. Lingkungan tempat anak mendapatkan pendidikan disebut sebagai lingkungan pendidikan. ${ }^{5}$

Ki Hajar Dewantara sebagai tokoh pendidikan mengemukakan konsep Tri Centra dengan menyatakan " Di dalam kehidupan anak ada tiga tempat pergaulan yang menjadi pusat pendidikan yang sangat penting baginya yaitu alam keluarga, alam perguruan dan alam pergerakan muda". ${ }^{6}$

Lingkungan sendiri dibagi menjadi 3 bagian. Yaitu lingkungan in formal, formal dan non formal. $^{7}$ Adapun lingkungan in formal adalah Keluarga, keluarga merupakan lingkungan pendidikan yang pertama, karena dalam keluarga inilah anak pertama kali mendapatkan didikan dan bimbingan. Juga dikatakan sebagai lingkungan pertama karena sebagian besar dari kehidupan anak berasal dari dalam keluarga. Tugas utama dari keluarga bagi pendidikan anak adalah sebagai peletak dasar bagi pendidikan akhlak dan pandangan hidup keagamaan. Sifat dan tabiat anak sebagian besar diambil dari kedua orang tuanya dan anggota keluarga lainnya,. Dalam keluarga pula ia menemukan dimana ia menjadi diri sendiri dan pribadi sendiri, keluarga juga merupakan wadah bagi anak dalam konteks proses belajarnya untuk membentuk dan mengembangkan diri dalam fungsi sosialnya. Disamping itu keluarga adalah tempat belajar belajar bagi anak dalam segala sikap untuk berbakti kepada Tuhan sebagai perwujudan nilai hidup tertinggi dengan demikian jelaslah bahwa peranan orang tua adalah tempat pengajaran dan kelangsungan pendidikan bagi anaknya. ${ }^{8}$

Adapun lingkungan formal dalam pendidikan yaitu lembaga pendidikan (sekolah). lingkungan sekolah merupakan sebab akibat dari terbatasnya pengetahuan serta tekhnologi yang tidak mampu di sampaikan orang tua. Sehingga dalam hal ini sekolah juga memiliki peran yang penting dalam pendidikan karena pengaruhnya yang besar sekali terhadap anak atau individu. Sekolah dikatakan sebagai tempat pendidikan formal karena di dalamnya memiliki dasar, tujuan, isi, metode, serta alat-alat yang disusun secara eksplisit, sistematis dan distandarisasikan.

\footnotetext{
${ }_{6}^{5}$ Abu Ahmadi dan Nur Uhbiyanti, Ilmu Pendidikan (Jakarta: Rineka Cipta, 2003), 64.

${ }^{6}$ Ibid, 172.

${ }^{7}$ Nur Fuadi, Profesionalisme Guru (Purwokerto: STAIN Press, 2012 ), 167-177.

${ }^{8}$ Abd. Muis Thabrani, Pengantar dan Dimensi-dimensi Pendidikan (Jember : STAIN Jember Press, 2013), 49.

138 | Falasifa, Vol. 11 Nomor 2 September 2020
} 


\section{Machfudz}

Menurut Syamsu Yusuf" menyatakan bahwa "Sekolah merupakan lembaga pendidikan formal yang secara sistematis melaksanakan program bimbingan, pengajaran dan latihan dalam rangka membantu siswa agar mampu mengembangkan potensinya, baik yang menyangkut moral, intelektual, spiritual, emosional, maupun sosial"

Lingkungan sosial atau non formal merupakan bagian dari lingkungan pendidikan dan pembelajaran bagi setiap individu. Setelah terlepas dari jam bersama keluarga ataupun ketika berada di luar sekolah, corak ragam yang diterima individu dalam masyarakat ini banyak sekali, meliputi segala bidang baik pembentukan kebiasaan, pembentukan pengetahuan, sikap dan minat maupun pembentukan kesusilaan dan keagamaan.

Dalam konsep pendidikan, masyarakat diartikan sebagai sekumpulan orang dengan berbagai ragam kualitas diri dari yang tidak berpendidikan sampai yang berpendidikan tinggi. Baik buruknya kualitas masyarakat di tentukan oleh kualitas pendidikan anggotanya, semakin tinggi pendidikannya semakin baik pula kualitas masyarakat secara keseluruhan. Ditinjau dari lingkungan pendidikan, masyarakat disebut sebagai lingkungan pendidikan non formal yang memberikan pendidikan secara sengaja dan berencana kepada seluruh anggotanya, tetapi tidak secara sistematis. ${ }^{10}$

Adapun kelas Menurut pengertian tradisional, diartikan sebagai tempat, di mana sekelompok siswa - siswi berkumpul untuk mengikuti kegiatan belajar mengajar. Kelas dalam pengertian yang demikian mengandung sifat statis dan tidak menunjukkan adanya suatu kedinamisan dalam proses belajar mengajar. Pengertian demikian menggambarkan bahwa proses belajar mengajar di kelas bersifat teacher centered tidak menekankan pada Student Active Learning. Tugas seorang guru hanyalah menyampaikan pelajaran dan siswa mendengarkan bersama - sama apa yang dijelaskan oleh guru. ${ }^{11}$

\section{PEMBAHASAN}

\section{Pembelajaran}

Pembelajaran merupakan terjemahan dari kata bahasa inggris "instruction", terdiri dari dua kegiatan utama yaitu belajar (learning) dan mengajar (teaching) kemudian di satukan dalam

\footnotetext{
${ }^{9}$ Syamsu Yusuf, Psikologi Perkembangan Anak dan Remaja (Bandung : PT. Remaja Rosda karya, 2001), 54.

${ }^{10}$ Nurfuadi. Profesionalisme Guru.( Porwokerto: Penerbit STAIN Press, 2012), 180

${ }^{11}$ Zuldafrial, Startegi dan Pendekatan Pengelolaaan kelas, cet II (Surakarta : Yuma Pustaka, 2012), 46.
} 
satu aktivitas, yaitu kegiatan belajar mengajar yang selanjutnya populer dengan sebutan pembelajaran (instruction). ${ }^{12}$

Menurut aliran behavioristik pembelajaran adalah suatu usaha guru membentuk tingkah laku yang di inginkan dengan menyediakan lingkungan atau stimulus. Aliran kognitif mendefinisikan pembelajaran sebagai cara guru memberikan kesempatan kepada siswa untuk berpikir agar mengenali dan memahami sesuatu yang sedang di pelajari. ${ }^{13}$ Menurut Oemar Hamalik ${ }^{14}$ Pembelajaran adalah suatu kombinasi yang tersusun meliputi unsur-unsur manusiawi, material, fasilitas, perlengkapan, dan prosedur yang saling mempengaruhi mencapai tujuan pembelajaran. Menurut Nurfuadi ${ }^{15}$ pembelajaran adalah suatu usaha yang sengaja melibatkan dan menggunakan pengetahuan profesional yang dimiliki guru untuk mencapai tujuan kurikulum. Dari kedua pendapat tersebut dapat disimpulkan, pembelajaran adalah suatu aktivitas yang dengan sengaja untuk memodifikasi berbagai kondisi yang diarahkan untuk mencapai suatu tujuan, yaitu tercapainya tujuan kurikulum.

\section{Lingkungan pembelajaran.}

Sebelum menuju dalam pembahasan inti mengenai lingkungan pembelajaran, penulis memaparkan sedikit mengenai lingkungan pendidikan yang merupakan penjabaran lebih luas dari adanya lingkungan pembelajaran. Dalam ranah pendidikan, lingkungan terbagi menjadi 3, yaitu :

\section{Keluarga}

Manusia ketika dilahirkan di dunia dalam keadaan lemah tanpa pertolongan orang lain terutama orang tuanya ia tidak bisa berbuat banyak. Dibalik keadaan yang lemah itu ia memiliki potensi baik yang bersifat jasmani maupun rohani. Keluarga sebagai lingkungan pendidikan pertama sangat penting dalam membentuk pola kepribadian anak. Karena dalam keluarga anak pertama kali berkenalan dengan nilai dan norma. Dalam Kemendibud, 0186/P/1984 menyatakan "Pendidikan keluarga memberikan pengetahuan dan keterampilan dasar, agama, dan

\footnotetext{
${ }^{12}$ TIM Pengembangan MKDP Kurikulum dan Pembelajaran, Kurikulum dan pembelajaran (Jakarta : PT Raja Grafindo Persada, 2011), 180.

${ }^{13}$ Darsono, Max, dkk. Belajar dan Pembelajaran. (Semarang: CV.IKIP Semarang Press, 2000), 69.

${ }^{14}$ Oemar Hamalik. Proses Belajar Mengajar, (Jakarta: PT Bumi Aksara. 2011), 52.

${ }^{15}$ Nurfuadi. Profesionalisme Guru.( Porwokerto: Penerbit STAIN Press, 2012), 134.

140 | Falasifa, Vol. 11 Nomor 2 September 2020
} 


\section{Machfudz}

kepercayaan. Nilai moral, norma sosial dan pandangan hidup yang diperlukan peserta didik untuk dapat peran dalam keluarga dan dalam masyarakat". ${ }^{16}$

Keluarga merupakan lingkungan pertama bagi anak, dilingkungan keluarga anak pertama kali mendapatkan pengaruh sadar, karena itu keluarga juga dapat dikatan sebagai lembaga pendidikan tertua yang bersifat informal dan kodrati. Keluarga merupakan lembaga pendidikan yang tidak mempunyai program resmi seperti yang dimiliki lembaga pendidikan formal. ${ }^{17}$

Fungsi lembaga pendidikan keluarga, yaitu :

1) Merupakan pengalaman pertama bagi masa kanak-kanak, pengalaman ini merupakan faktor yang sangat penting bagi perkembangan berikutnya, khususnya dalam perkembangan pribadinya. Kehidupan keluarga sangatlah penting, sebab pengalaman masa kanak-kanak akan memberi warna pada perkembangan berikutnya.

2) Pendidikan di lingkungan keluarga dapat menjamin kehidupan emosional untuk anak tumbuh dan berkembang. Kehidupan emosional ini sangat penting dalam pembentukan pribadi anak, hubungan emosional yang kurang dan berlebihan akan banyak merugikan perkembangan anak.

3) Dalam keluarga akan terbentuk pendidikan moral. Keteladalan orangtua dalam bertutur kata dan berperilaku sehari-hari akan menjadi warna pendidikan moral anak dalam keluarga tersebut, guna membentuk manusia susila.

4) Di dalam keluarga akan tumbuh sikap tolong menolong, tenggang rasa, sehingga tumbuh kehidupan keluarga yang damai dan sejahtera. Setiap anggota keluarga memiliki sikap sosial yang mulia, dengan cara demikian keluarga akan menjadi wahana pembentukan manusia sebagai makhluk sosial.

5) Keluarga merupakan lembaga yang memang berperan dalam meletakkan dasardasar pendidikan agama. Kebiasaan orang tua membawa anaknya ke masjid merupakan langkah yang bijaksana dari keluarga dalam upaya pembentukan anak sebagai makhluk religius.

${ }^{16}$ Fuad Ihsan, Dasar-dasar Kependidikan (Jakarta : PT. Rineka Cipta, 2008) hal 16-17
${ }^{17}$ Nurfuadi. Profesionalisme Guru.( Porwokerto: Penerbit STAIN Press, 2012), 167.

Falasifa, Vol. 11 Nomor 2 September 2020 | 141 
6) Di dalam konteks membangun anak sebagai makhluk individu diarahkan agar anak dapat mengembangkan dan menolong dirinya sendiri. Dalam konteks ini keluarga lebih cenderung untuk menciptakan kondisi yang dapat menimbulkan inisiatif, kreatifitas, kehendak, emosi, tanggung jawab, ketermpilan, dan kegiatan lain sesuai dengan apa yang ada dalam keluarga . sedangkan dalam perkembangan, konsep, prinsip, generalisasi dan intelek, sebagai keluarga karena keterbatasannya hanya berfungsi sebagai pendorong dan pemberi semangat. ${ }^{18}$

Lingkungan keluarga merupakan lingkungan yang pertama, karena dalam keluarga inilah anak pertama-tama mendapatkan didikan dan bimbingan. Juga dikatakan lingkungan yang utama, karena sebagian besar dari kehidupan anak adalah di dalam keluarga, sehingga pendidikan yang banyak diterima anak adalah dari keluarga. ${ }^{19}$ Tugas utama dari keluarga bagi pendidikan anak adalah sebagai peletak dasar bagi pendidikan akhlak dan pandangan hidup keagamaan. Sifat dan tabiat anak kebanyakan diambil dari kedua orang tuanya dan dari anggota keluarga lain. Keluarga sebagai institusi atau lembaga (in formal) sebagaimana hadist nabi yang artinya: 20 " Setiap anak yang lahir itu, dilahirkan atas dasar islam, hanya kedua orangtualah yang dapat menjadikannya yahudi, nastani atau majusi"

Dari hadist tersebut dapat kita lihat bahwa keluarga merupakan tempat pendidikan yang utama sehingga memberikan warna yang dominan bagi anak, sejak ia dilahirkan, ia menerima bimbingan kebaikan dari keluarga yang memungkinkannya berjalan di jalan keutamaan sekaligus bisa berperilaku di jalan kejelekan sebagai akibat dari pendidikan kelurga yang salah.

Adapun dasar-dasar tanggung jawab orangtua terhadap pendidikan anaknya meliputi hal-hal berikut :

1) Adanya tradisi atau cinta kasih yang menjiwai hubungan orangtua dan anak. Kasih sayang orang tua yang ikhlas dan murni akan medorong sikap dan tindakan

\footnotetext{
${ }^{18}$ Ibid, 18-19.

${ }^{19}$ Abd. Muis Thabrani, Pengantar dan Dimensi-dimensi Pendidikan (Jember : STAIN Jember Press, 2013), 49.

${ }^{20}$ Noor Aufashiddiq. Terjemah kitab ta'lim muata'alim (Surabaya : Al-Hidayah), 22.

142 | Falasifa, Vol. 11 Nomor 2 September 2020
} 


\section{Machfudz}

rela menerima tanggung jawab untuk mengorbankan hidupnya dalam memberikan pertolongan kepada anaknya.

2) Sebagaimana tanggung jawab orang tua terhadap pendidikan anaknya, orang tua perlu membekali anaknya dengan ilmu pengetahuan dan keterampilan yang berguna bagi kehidupan anaknya kelak, sehingga pada masa dewasanya mampu mandiri dan bermanfaat bagi kehidupan sosial, negara dan agamanya.

3) Kebahagiaan anak akan menjadi bagian dari kebahagiaan orangtua . oleh sebab itu, orang tua harus senantiasa mengupayakan kebahagiaan anak dalam kapasitas pemenuhan kebutuhan sesuai dengan perkembangan usianya, yang diiringi dengan memberikan pendidikan agama dan akhlak yang baik. ${ }^{21}$

Untuk melaksanakan berbagai tanggung jawab itu, dalam konsep pendidikan modern, orang tua seyogyanya bersikap demokratis terhadap anaknya. Artinya orang tua mampu menciptakan suasana dialogis dengan anak, sehingga menumbuhkan hubungan keluarga yang harmonis, saling menghormati, disiplin, dan tahu tanggung jawab masing-masing suasana demikian akan sangat mendukung keprbadian anak sehingga anak akan terbiasa dengan sikap yang baik dilingkungan, baik dilingkungan keluarga,sekolah maupun masyarakat. ${ }^{22}$

Lingkungan keluarga yang baik setidaknya memiliki dua ciri sebagai berikut : pertama, Emosional. Bagaimana suatu kelurga memberikan suasana yang baik bagi anak-anaknya, seperti perasaan senang, aman, disayangi dan di lindungi. Suasana seperti demikian dapat tercipta makala kehidupan rumah tangga (suami-istri) di liputi suasana yang sama ${ }^{23}$ kedua, mengtahui dasar-dasar kependidikan terutama berkenaan dengan kewajiban dan tanggung jawab terhadap pendidikan anak serta tujuan dan isi pendidikan yang diberikannya. ${ }^{24}$

Berikut dipaparkan 5 fungsi keluarga :

1) Menjaga fitrah anak yang luhur dan suci.

2) Meluruskan fitrah dan membangkitkan serta mengembangkan bakat kemampuan positifnya.

\footnotetext{
${ }^{21}$ Nurfuadi. Profesionalisme Guru.( Porwokerto: Penerbit STAIN Press, 2012), 171

${ }^{22}$ Ibid, 169-170.

${ }^{23}$ Hery noer ali, Ilmu Pendidikan Islam (Jakarta : PT Logos Wacana Ilmu, 1999)

${ }^{24}$ Ibid, 215.
} 
3) Menciptakan lingkungan yang aman dan nyaman dan mengasuhnya di lingkungan yang di lingkupi kasih sayang lemah lembut dan saling mencintai.

4) Memberikan informasi pendidikan dan kebudayaan masyarakat, bahasa, adat istiadat dan norma-norma sosial. ${ }^{25}$

\section{Sekolah/Lembaga pendidikan}

Seperti konsep pendidikan yang dikemukakan oleh Ki Hajar Dewantoro bahwa sekolah merupakan lingkungan kedua atau disebut juga lingkungan formal dalam tri pusat pendidikan. ${ }^{26}$ Sekolah diartikan sebagai lingkungan pembelajaran di mana kegiatan pembelajaran lebih banyak dilakukan di ruangan kelas yang sudah disiapkan di sekolah, sehingga lebih efisien dengan adanya pengelompokan serta tingkatan dalam kelompok belajar.

Sekolah memegang peranan penting dalam pendidikan, karena memiliki pengaruh yang besar pada jiwa anak, maka selain keluarga sebagai pusat pendidikan, sekolah juga memiliki fungsi sebagai pusat pendidikan dalam membentuk pribadi anak. Sekolah sengaja di didrikan dan dibangun sebagai temat pendidikan, sehingga dikatakn sebagai lembaga pendidikan kedua setelah keluarga, yang memiliki fungsi melanjutkan pendidikan keluarga, dengan guru sebagai ganti orang tua yang di taati. ${ }^{27}$ Sekolah menyiapkan sarana dan prasarana, serta pengelolahan yang tersusun mengenai kurikulum dan pendidik yang terorganisir, serta adanya unit tempat berlangsunya pembelajaran yang di sebut ruang kelas. ${ }^{28}$

\section{Masyarakat}

Masyarakat juga dapat diartikan sebagai suatu kelompok manusia yang telah memiliki tatanan kehidupan, norma-norma, adat istiadat yang sama-sama di taati di lingkungannya. ${ }^{29}$ Pendidikan masyarakat bertumpu pada landasan afeksi masyarakat. Dalam artian ini masyarakat adalah wadah dan wahana pendidikan, medan kehidupan manusia yang majemuk. (plural : suku,agama, ekonomi dan lain sebagainya).

\footnotetext{
${ }^{25}$ M.Sholikodin Djaelani, Peran Pendidikan Agama Islam Dalam Keluarga Dan Masyarakat Dalam Jurnal Ilmiyah Widya . Vol.i no. 2

${ }^{26}$ Abu Ahmadi dan Nur uhbiyanti, Ilmu Pendidikan (Jakarta: Rineka Cipta, 2003), 64.

${ }^{27}$ Ibid, 181.

${ }^{28}$ Zuldafrial, Startegi dan Pendekatan Pengelolaaan kelas, cet II (Surakarta : Yuma Pustaka, 2012), 45

${ }^{29}$ Abu ahmadi. Sosioogi Pendidikan (Jakarta : Rineka Cipta. 2004) 97.

144 | Falasifa, Vol. 11 Nomor 2 September 2020
} 


\section{Machfudz}

Pendidikan yang didapatkan dari masyarakat dapat dikatakan sebagai pendidikan tidak langsung ,atau pendidikan tidak sadar yang dilakukan oleh masyarakat. Dan anak didik secara sadar ataupun tidak mendidik dirinya sendiri , mencari pengetahuan dan pengalaman sendiri, mempertebal keimanan serta keyakinan sendiri akan nilai-nilai kesusilaan dan keagamaan dalam masyarakat. ${ }^{30}$

Masyarakat turut serta memikul tanggung jawab pendidikan. Masyarakat besar pengaruhnya dalam memberi arah terhadap pendidikan anak, terutama para pemimpin masyarakat atau penguasa yang ada di dalamnya. Pemimpin masyarakat muslim tentu saja menghendaki agar setiap anak didiknya menjadi anggota yang taat patuh menjalankan agamanya, baik dalam lingkungan keluarga, anggota sepermainannya, kelompok kelas dan sekolahnya. ${ }^{31}$

Di samping para pemimpin, semua anggota masyarakat juga harus ikut serta memikul tanggung jawab membina dan meningkatkan pendidikan masyarakat dengan mengajak kepada yang ma'ruf dan mencegah yang munkar. Sebagaimana yang tertera dalam Surah Ali Imran (3): 104, yang berbunyi:

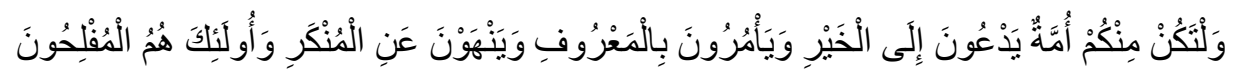

Artinya: " Dan hendaklah ada diantara kamu segolongan umat yang menyeru kepada kebajikan, menyuruh kepada yang ma'ruf dan mencegah dari yang munkar merekalah orang-orang yang beruntung. “ 32

Kehidupan masyarakat di lingkungan sekolah selain dapat digunakan sebagai contoh dalam pembelajaran juga mempunyai peran untuk ikut serta dalam praktik kelancaran penyelenggaran pendidikan. Keberadaan masyarakat dalam pendidikan mengacu pada UU nomer 20 tahun 2003 tentang sistem pendidikan nasional pasal 8 yang berbunyi "Masyarakat berhak berperan serta dalam perencanaan, pelaksanaan, pengawasan, dan evaluasi program pendidikan" ${ }^{33}$ dan pasal 9 yang berbunyi sebagai berikut "Masyarakat berkewajiban memberikan dukungan sumber daya dalam penyelenggaraan pendidikan". ${ }^{34}$

\footnotetext{
${ }^{30}$ Zuhairi , Filsafat Pendidikan Islam ( Jakarta : Bumi Aksara. 2009) 180.

${ }^{31}$ Zakiah Drajat, Ilmu Pendidikan Islam, (Jakarta: Bumi Aksara, 2014), 45.

${ }^{32}$ Al-Qur;an, 3:104

${ }^{33}$ Sekertariat Negara RI, Undang-undang No. 20 Tahun 2003 tentang Sistem Pendidikan Nasional

${ }^{34}$ Sekertariat Negara RI, Undang-undang No. 20 Tahun 2003 tentang Sistem Pendidikan Nasional
} 
Namun Kehidupan masyarakat disekitar sekolah tentunya mempunyai bermacam-macam karakter dan juga profesi hal ini dapat dijelaskan melalui contoh misalnya dilingkungan luar sekolah terdiri dari orang-orang yang tidak terpelajar, penjudi, suka mencuri dan mempunyai kebiasaan yang baik akan mempunyai pengaruh yang buruk terhadap siswa yang berada disitu akibatnya pembelajaran akan terganggu dan bahkan kehilangan semangat belajar karena perhatiannya yang semula terpusat oleh pelajaran berpindah pada kegiatan yang dilakukan pada orang-orang yang berada disekitarnya.

Sebaliknya jika masyarakat yang hidup dalam lingkungan sekolah adalah orang-orang terpelajar, yang mendidik anak-anaknya untuk bersekolah, antusias akan cita-cita yang luhur yaitu masa depan anaknya maka mereka juga akan terpengaruh ke dalam hal yang baik sehingga dapat mendorong mereka lebih giat belajar.

Sebagai salah satu lingkungan terjadinya kegiatan pendidikan, masyarakat mempunyai pengaruh yang sangat besar terhadap berlangsungnya semua aktivitas yang berkaitan dengan pendidikan. Generasi muda adalah generasi yang akan meneruskan kehidupan masyarakat itu sendiri, baik di jalur pendidikan sekolah mupun jalur pendidikan luar sekolah. Karenanya, bahan yang akan diberikan kepada anak didik sebagai generasi penerus bangsa harus disesuaikan dengan keadaan dan tuntutan masyarakat dimana kegiatan pendidikan berlangsung. Adapun beberapa peran dari masyarakat terhadap pendidikan adalah sebagai berikut: ${ }^{35}$

a) Masyarakat berperan serta dalam mendirikan dan membiayai sekolah.

b) Masyarakat sebagai pengawas pendidikan agar sekolah terus membantu dan mendukung cita-cita dan kebutuhan masyarakat.

c) Masyarakat berpartisipasi dalam menyediakan sumber-sumber belajar, seperti gedung museum, perpustakaan, panggung-panggung kesenian, kebun binatang dan sebagainya.

d) Masyarakat menyediakan sumber belajar yang dapat didatangkan ke sekolah. Di dalam masyarakat, banyak orang-orang yang mempunyai keahlian khusus seperti petani, peternak, saudagar, polisi, dokter dan sebagainya. Berbagai macam profesi

\footnotetext{
${ }^{35}$ Hasbullah. 2013. Dasar-dasar Ilmu Pendidikan. Jakarta: PT. Raja Grafindo Persada. 146 | Falasifa, Vol. 11 Nomor 2 September 2020
} 


\section{Machfudz}

tersebut dapat dijadikan sebagai narasumber dalam suatu kegiatan workshop/seminar dalam upaya menambah wawasan dan pengetahuan peserta didik.

e) Masyarakat sebagai sumber pelajaran atau laboratorium tempat belajar.

Peran masyarakat di sini adalah memberikan bahan pelajaran dalam wujud aspek alami industri, perumahan, transportasi, perkebunan, pertambangan, dan sebagainya. Dengan mengacu pada hal di atas, nampak jelas bahwa masyarakat memiliki peran yang sangat besar terhadap pendidikan sekolah. Karenanya, sekolah perlu memanfaatkan sebaik-baiknya peran dari masyarakat, dengan pertimbangan alasan sebagai berikut:

a) Dengan melihat realita dalam masyarakat, anak didik akan mendapatkankan pengalaman langsung sehingga mereka dapat memiliki pengalaman yang konkret dan lebih mudah untuk diingat.

b) Pendidikan membina anak-anak yang berasal dari masyarakat dan akan kembali ke masyarakat.

c) Banyak sumber pengetahuan di masyarakat yang belum diketahui oleh guru.

d) Pada kenyataannya, antara masyarakat dan sekolah keduanya saling membutuhkan antara satu dengan lainnya. Adanya keterlibatan siswa dalam kegiatan yang ada dalam masyarakat makan akan menguntungkan terhadap perkembangan pribadinya. Namun ketika keterlibatan siswa dalam kegiatan masyarakat terlalu padat, seperti berorganisasi, kegiatan-kegiatan sosial, keagamaan, dan lain-lain maka akan mengganggu belajarnya. Lebih-lebih jika tidak bijaksana dalam mengatur waktu, maka belajarnya akan semakin terbengkalai dan terlupakan. Dengan demikian, membatasi kegiatan siswa dalam masyarakat sangatlah perlu, hal demikian agar tidak sampai mengganggu belajarnya. Namun demikian, kegiatan yang mendukung belajar seperti kursus, PKK Remaja, kelompok diskusi dan semisalnya tidaklah menjadi masalah. ${ }^{36}$

Lingkungan pembelajaran merupakan suatu tempat, di mana siswa dan guru melakukan interaksi belajar. Dalam hal ini, yang di maksud dengan lingkungan pembelajaran yaitu

\footnotetext{
${ }^{36}$ Daryanto. 2013. Belajar dan Mengajar. Bandung: Yrama Wydia
} 
lingkungan yang lebih di khususkan atau lebih di fokuskan dalam terjadinya proses pembelajaran. Dalam skripsi ini pembahasan lingkungan pembelajaran, tertuju pada sekolah dan ruang kelas.

Sekolah adalah suatu lembaga pendidikan formal,pada dasarnya merupakan suatu lembaga yang membantu bagi terciptanya cita - cita keluarga dan masyarakat yang secara resmi menyelenggarakan kegiatan pembelajaran secara sistematis, berencana, terarah, yang dilakukan oleh pendidik yang profesional, dengan program yang dituangkan ke dalam kurikulum tertentu dan diikuti oleh peserta didik pada jenjang tertentu mulai dari taman kanak-kanak (TK) sampai perguruan tinggi (PT).

Sekolah merupakan lingkungan artifisial yang sengaja dibentuk guna untuk mendidik dan membina generasi muda ke arah tujuan tertentu, terutama untuk membekali anak dengan pengetahuan dan kecakapan hidup (life skill) yang dibutuhkan di kemudian hari. Sebagai lembaga pendidikan, sekolah mempunyai pengaruh yang cukup besar terhadap perkembangan anak-anak dan remaja. ${ }^{37}$

Sekolah melakukan pembinaan pendidikan kepada peserta didik yang didasarkan kepada kepercayaan yang diberikan keluarga dan masyarakat. Kondisi itu muncul karena keluarga dan masyarakat memiliki keterbatasan dalam melaksanakan pendidikan. Tetapi, tanggung jawab pendidikan anak seutuhnya menjadi tanggung jawab orang tua. Sekolah hanya meneruskan dan mengembangkan pendidikan yang telah di peroleh dilingkungan keluarga sebagai lingkungan pendidikan in formal yang telah di kenal anak sebelumnya.

Sekolah juga merencanakan bermacam-macam lingkungan pendidikan dan menyediakan berbagai kesempatan bagi peserta didik untuk melakukan berbagai kegiatan belajar. Tujuannya ialah membantu orang belajar atau memanipulasi (merekayasa) lingkungan sehingga memberi kemudahan bagi orang yang belajar. Sekolah merupakan salah satu institusi sosial yang mempengaruhi proses sosialisasi dan berfungsi mewariskan kebudayaan masyarakat kepada anak. Sekolah merupakan suatu sistem sosial yang mempunyai organisasi yang unik dan pola relasi sosial di antara para anggotanya yang bersifat unik pula. Ini kita sebut kebudayaan sekolah.

1. Kualitas belajar

\footnotetext{
${ }^{37}$ Desmita, Psikologi perkembangan anak didik (Bandung: PT. Remaja Rosda Karya, 2014) 222 148 | Falasifa, Vol. 11 Nomor 2 September 2020
} 


\section{Machfudz}

Seperti yang sudah peneliti paparkan pada definisi istilah mengenai kualitas belajar. Kualitas belajar dibagi menjadi 2, yaitu: akademik dan non akademik.

a. Akademik

Kata akademik berasal dari bahasa Yunani yaitu academos yang yaitu sebuah taman umum yang berada di barat laut kota Athena yang kemudian kata academos berubah menjadi akademik yaitu semacam tempat perguruan. Dalam hal akademik, pendidikan selalu memajukan kualitas atau mutumya dalam hal prestasi.

1) Macam - macam kemampuan akademik

Crow $^{38}$ mengklasifikasikan kemampuan akademik menjadi tiga bagian, yaitu :

a) Kemampuan bahasa

Semakin berkembangnya seseorang menuntut ia untuk memiliki penalaran yang lebih tinggi, hal tersebut sangat bergantung pada penggunaan bahasa. Menurut judd, bahasa adalah alat untuk membangun dan membentuk hubungan yang memperluas pengetahuan.

b) Kemampuan matematika

Menurut Wrightstone, kemampuan berhitung memiliki fungsi yaitu menekankan berpikir dalam menghadapi situasi yang memerlukan pengalaman - pengalaman yang berhubungan dengan angka.

c) Kemampuan ilmu pengetahuan/Sains

Dalam dunia yang dipenuhi dengan produk-produk kerja ilmiah, literasi sains menjadi suatu keharusan bagi setiap orang. Setiap orang perlu menggunakan informasi ilmiah untuk melakukan pilihan yang dihadapinya setiap hari. Melalui studi ilmu pengetahuan bertambahlah pengetahuan siswa tentang dunia.

2) Penilaian akademik

Penilaian merupakan proses sistematis yang mengandung pengumpulan informasi, menganalisis dan menginterpretasi suatu informasi untuk membuat keputusan keputusan. ${ }^{39}$

${ }^{38}$ Lester D. Crow dan Alice.crow, Psychologi Pendidikan Terjemahan Abdul Rachman Abror (Yogyakarta: Nur Cahaya, 1989) 309.

${ }^{39}$ Depdiknas. Kerangka Dasar Kurikulum (Jakarta: Pusat Kurikulum. 2004)

Falasifa, Vol. 11 Nomor 2 September 2020 | 149 
Sedangkan menurut O. Hamalik, penialaian adalah suatu proses berkelanjutan tentang pengumpulan dan penafsiran informasi untuk menilai keputusan yang dibuat dalam merancang suatu sistem pengajaran. ${ }^{40}$

Penilaian adalah suatu kegiatan untuk membuat keputusan tentang hasil pembelajaran dari masing-masing siswa, serta keberhasilan siswa dalam kelas secara keseluruhan. Penilaian juga merupakan indikator keberhasilan guru dalam proses pembelajaran. ${ }^{41}$

\section{Peran lingkungan pembelajaran dalam meningkatkan kualitas belajar}

Dari penjelasan di atas mengenai lingkungan pembelajaran dan juga kualitas belajar. Berikut penulis memaparkan mengenai bagaimana peran lingkungan pembelajaran dalam meningkatkan kualitas belajar. Sebagaimana yang kita ketahui dalam dunia pendidikan, bahwasanya lingkungan merupakan salah satu komponen dari pendidikan. Jika hal itu tidak ada maka tidak dapat dikatakan sebagai pendidikan. Selain sebagai komponen pendidikan, lingkungan juga memiliki peran yang dapat mempengaruhi bagaimana proses dan hasil dari suatu pendidikan. tetapi dalam hal ini, penulis memfokuskan pada pembelajaran yang dilakukan di lingkungan sekolah dan juga lingkungan kelas.

Pendidikan formal yang dilakukan di sekolah pastinya memiliki lingkungan yang tertata sesuai dengan apa yang dijadikan peraturan maupun ketentuan dalam sekolah tersebut. Karena setiap sekolah pasti memiliki visi dan misi dalam meningkatkan kedisiplinan,akhlak serta prestasi siswa, sehingga hasil output dari sekolah tersebut mimiliki bobot yang baik. Menurut Nanang Hanifa dan Cucu Suhana bahwasanya indikator dalam pendidikan mencakup input, proses dan output pendidikan. Adapun kualitas belajar siswa mengacu pada prestasi yang di capai oleh siswa baik dalam segi akademik ataupun non akademik ${ }^{42}$, sehingga dalam hal ini lingkungan sekolah sangat berpengaruh dalam proses belajar siswa, mengapa demikian, karena dalam suatu sekolah komponen pembangun lingkungan terdiri dari beragam hal, seperti guru, murid, fasilitas sekolah, dan juga pembelajaran yang diadakan.

Dalam hal ini peran lingkungan sekolah dan juga kelas pada penelitian yang dilakukan penulis berpengaruh penting dalam pencapaian kualitas belajar siswa utamanya di kelas, karena

\footnotetext{
${ }^{40}$ Oemar Hamalik, Perencanaan pengajaran berdasarkan pendekatan sistem (Jakarta: PT. Bumi Aksara. 2000)

${ }^{41}$ Supratiningsih dan Suharja, 2006

${ }^{42}$ Nanang Hanifa dan Cucu Suhana, Konsep Strategi pembelajaran. 83-86

150 | Falasifa, Vol. 11 Nomor 2 September 2020
} 


\section{Machfudz}

kebutuhan fasilitas yang sudah di sediakan, guru-guru yang linier sesuai dengan mata pelajaran yang diajarkan, serta beberapa media pendukung dalam pembelajaran sehingga kualitas belajar siswa dinilai baik. Hal ini di buktikan dengan capaian prestasi baik secara akademik maupun non akademik.

Adapun capaian yang dinilai dari peran lingkungan pembelajaran dalam kualitas non akademik siswa, yaitu pada kegiatan tambahan /ekstrakulikuler yang di adakan di sekolah, serta mengenai akhlak dan juga etika siswa, baik di dalam lingkungan sekolah ataupun luar lingkungan sekolah.

\section{KESIMPULAN}

Lingkungan pembelajaran merupakan tempat terjadinya pembelajaran yang secara langsung mempengaruhi bagaiman proses pembelajaran berlangsung. Jika lingkungan tersebut baik, kondisional dan segala kebutuhan dalam pembelajaran terpenuhi. Maka proses pembelajaran akan berjalan dengan baik dan efisien sesuai dengan apa yang dikehendaki dan di inginkan. Pentingnya peran lingkungan pembelajaran dapat kita lihat dari hasil atau output siswa yang di luluskan dari sekolah tersebut. Di madrasah sendiri, siswa diarahkan untuk belajar ke jenjang selanjutnya, agar mereka lebih paham sebelum terjun ke lapangan pekerjaan seperti yang mereka cita-citakan. Melalui pengenalan lingkungan pembelajaran siswa dapat mengerti bagaimana lingkungan belajar yang baik dan membantu meningkatkan kualitas belajar mereka. Peran lingkungan pembelajaran dalam meningkatkan kualitas akademik adalah dengan adanya sarpras yang mendukung, menejemen kelas yang baik, sumber belajar yang berkualitas, serta pengelolaan kelas yang baik. Dapat mempengaruhi bagaimana pola belajar siswa sehingga kualitas penilaian mereka pun baik, dan di buktikan dengan adanya output yang berkualitas pula. Karena dalam dunia pendidikan, selain skill penilaian pun dianggap perlu, sebagai tolak ukur kemampuan siswa dalam hasil belajarnya. Peran lingkungan pembelajaran dalam meningkatkan kualitas non akademik adalah melalui ekstakulikuler, etika dan akhlak. Sebagai seorang pengajar dan pendidik guru dapat mengukur kemampuan skill non akademik siswa, serta melihat perkembangan tingkah laku siswanya, apakah buruk menjadi semakin baik ataupun kebalikannya, sehingga peran lingkungan dalam kegiatan on akademik pundapat terkontrol dan lebih menjadi perhatian sebagai pencetak siswa yang berprestasi, berkualitas dan memiliki akhlak yang baik.

Falasifa, Vol. 11 Nomor 2 September 2020 | 151 


\section{DAFTAR PUSTAKA}

Abu Ahmadi dan Nur uhbiyanti, Ilmu Pendidikan, Jakarta: Rineka Cipta, 2003.

Abu Ahmadi. Sosioogi Pendidikan, Jakarta : Rineka Cipta. 2004.

Abd. Muis Thabrani, Pengantar dan Dimensi-dimensi Pendidikan, Jember: STAIN Jember Press, 2013.

Daryanto. 2013. Belajar dan Mengajar. Bandung: Yrama Wydia.

Desmita, Psikologi perkembangan anak didik, Bandung: PT. Remaja Rosda Karya, 2014.

Depdiknas. Kerangka Dasar Kurikulum, Jakarta: Pusat Kurikulum. 2004.

Departemen Pendidikan Nasional, Kamus Besar Bahasa Indonesia, Jakarta: Balai Pustaka, 2007.

Darsono, Max, dkk. Belajar dan Pembelajaran, Semarang: CV.IKIP Semarang Press, 2000.

Hasbullah. 2013. Dasar-dasar Ilmu Pendidikan. Jakarta: PT. Raja Grafindo Persada.

Hery Noer Ali, Ilmu Pendidikan Islam, Jakarta: PT Logos Wacana Ilmu, 1999.

Lester D. Crow dan Alice.crow, Psychologi Pendidikan Terjemahan Abdul Rachman Abror, Yogyakarta: Nur Cahaya, 1989.

Oemar Hamalik, Perencanaan pengajaran berdasarkan pendekatan sistem, Jakarta: PT. Bumi Aksara. 2000.

Nur Fuadi, Profesionalisme Guru, Purwokerto: STAIN Press, 2012.

Oemar Hamalik. Proses Belajar Mengajar, Jakarta: PT Bumi Aksara. 2011.

Fuad Ihsan, Dasar-dasar Kependidikan, Jakarta: PT. Rineka Cipta, 2008.

Noor Aufashiddiq. Terjemah kitab ta'lim muata'alim, Surabaya : Al-Hidayah

M.Sholikodin Djaelani, Peran Pendidikan Agama Islam Dalam Keluarga Dan Masyarakat Dalam Jurnal Ilmiyah Widya . Vol.i no. 2

Sekertariat Negara RI, Undang-undang No. 20 Tahun 2003 tentang Sistem Pendidikan Nasional Syamsul Yusuf, Psikologi Perkembangan Anak dan Remaja, Bandung: PT. Remaja Rosda karya, 2001.

TIM Pengembangan MKDP Kurikulum dan Pembelajaran, Kurikulum dan pembelajaran Jakarta: PT Raja Grafindo Persada, 2011.

Undang-undang Sistem Pendidikan Nasional No. 20 tahun 2003, Bandung: Citra Umbara, 2006.

Zuldafrial, Startegi dan Pendekatan Pengelolaaan kelas, cet II, Surakarta: Yuma Pustaka, 2012

Zuhairi , Filsafat Pendidikan Islam, Jakarta : Bumi Aksara. 2009.

Zakiah Drajat, Ilmu Pendidikan Islam, Jakarta: Bumi Aksara, 2014. 